\title{
ENVIRONMENTAL REGULATION OF TRACE ELEMENTS IN SOILS OF MOLDOVA
}

\author{
Vladimir Kiriliuc \\ Institute of Pedology, Agrochemistry and Soil Protection "Nicolae Dimo", \\ MD-2070, Chisinau, str. Ialoveni, 100,ipaps_dimo@mtc.md
}

\begin{abstract}
The scale of environmental regulation (content and pollution levels) of trace element in soils of Moldova was proposed. Contamination levels are justified, depending on the adverse effects that have trace elements in soils, plants, groundwater and more - per person. Proposed scale has 6 content and 4 pollution levels. Along with equalized MPC it may help to consider a number of deficiencies that are met in this area and improve the practical application of the assessment of soil contamination. Scale Indicators are flexible values, taking the large variability content of trace elements.
\end{abstract}

Key words: environmental regulation, trace elements, soils, pollution level, indicators

\section{Introduction}

Saving the biosphere in the native status under current conditions is practically impossible, since the entire surface of the globe is more or less exposed to anthropogenic products. Consequently, the question is not whether to have a clean environment, but the levels of the chemical elements of biospheres are in amounts that not lead to negative consequences. The need to determine the maximum permissible concentration (MPC) of a number of elements emerged with increased reports of adverse effects of contamination of soil and water, which are manifested in the reduction of yield, worsening the hygienic quality of production, diseases of livestock, infringement of normal human life.

Heavy metals are polyvalent, well-absorbed by organically substances and soil colloidal complex, forming insoluble compounds, which contributes to their gradual accumulation in soils. The accumulation of chemical elements increases the toxic potential of soils, so its necessary to determinate what levels of concentration can bring the contents of each elements - pollutants, without fearing the consequences. Development of theoretical bases and practical methods of determination of MPC elements in soils is a difficult task and the work started later than in other environmental components.. Not by chance, currently established the MPC only for hundreds of substances that pollute the soil, while the number of MPC - polluting water sources, more than 800, polluting the atmosphere - about 300 [1].

Principles of chemical substances regulation in soils differ from those bodies of water, air, food. This is due mainly to the fact that direct intake from soil to human body is limited and most often goes on the biological (food) chains: from the soil to plants and animals, water and air, to man. The problem is complicated by the fact that the state of chemical substances in soils is determined by a large number of influencing factors of soil are geological character. So considering all factors affecting a specific geochemical conditions in the state of elements of contaminations is difficult, sanitation-hygienic services for regulations of elements in soils is based on those soil, climatic, geochemical, biological experimental condition that provide to the maximum possible extent the ability of chemical elements to pass into the adjacent environment. This work was carried out experimentally and the present sanitary-hygienic system MPC has played a great role in the environment protection of soils, plants and water [1,2].

Moldova is a young state, and in spite of the great scientific potential, normalization of all chemical contaminants to re-complete the scheme is not possible. In the former Soviet Union the costs of establishing a standard in one environment habitat were 50 thousand rubles, in 2011 - 50 thousands of Euros [3]. Easy to re-approve the world (European) MPC or neighboring states MPC without analytical consideration leads to large errors and problems $[4,5]$. Application of the calculation method for determining the approximate temporary MPC based on physic-chemical and toxic properties of individual contaminants classes of compounds requires further verification to complete the scheme.

The method proved to be reliable, but again needs a long time. Today's requirement is to have a real MPC or MAC (other indicators), to properly assess the degree of soil pollution by chemical elements - pollutants. Quantity of elementpollutant in the soil below MPC is considered hygienic standard MPC. For assessment and management of hygienic standards MPC are taken into account several factors, in particular:

1. Concentration of the element-pollutant in soil;

2. Adsorption capacity of the soil;

3. Migration capacity of the element-pollutant and possibility migration ways and in connection with the ability of soil to self-purification, or conversely, to an accumulation of element-pollutant;

4. Toxic level of element-pollutants on biota (microorganisms, plant roots). 


\begin{tabular}{|c|c|c|c|c|c|c|c|c|c|c|c|c|c|c|c|c|c|c|c|}
\hline & & ' & $\underset{\infty}{\dot{1}} \stackrel{0}{\infty}$ & is & & \ั. & ì & $\frac{1}{a}$ 唡 & bi & ஓ & หั & \&్ల & ఏ్తి & & 空 & ¿্ণ & 힝 & ¿ & \\
\hline & 与 & - & $\begin{array}{l}8 \\
\stackrel{8}{0} \\
0 \\
0\end{array}$ & 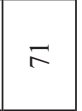 & & $\stackrel{\widetilde{V}}{\mathrm{~V}}$ & $\frac{8}{1}$ & $\frac{8}{\frac{8}{1}}$ & $\frac{1}{0} \stackrel{0}{9}$ & $\frac{1}{2}$ & 光 & $\stackrel{్}{~}$ & ถึ & & 辛 8 & i⿱宀 & : & $\begin{array}{l}\stackrel{\Lambda}{\Lambda} \\
\text { ¿ }\end{array}$ & 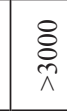 \\
\hline & & $m$ & $\dot{2} \stackrel{0}{0}$ & $\bar{\sigma}$ & & $\stackrel{?}{\mathrm{~V}}$ & $\begin{array}{l}\text { P } \\
\text { f } \\
\end{array}$ & $\div 8$ & $=$ & 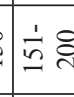 & ì & in & ฉ্ & & 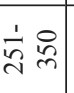 & 离 \& & 흠 & $\stackrel{8}{n}$ & in \\
\hline & & , & 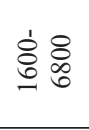 & 高 & & $\stackrel{\vec{\nabla}}{\mathrm{V}}$ & 㝘 ま & 客 ¿ & : & 客 & 客 & \&્ڤ & ठ్̊ి & & 它 。̊̊. & 客 \& & 光 & $\begin{array}{l}\stackrel{8}{0} \\
\stackrel{0}{0} \\
\wedge\end{array}$ & \\
\hline & $\overrightarrow{2}$ & $m$ & $\begin{array}{l}8 \\
\text { †े } \\
\text { in } \\
\text { in }\end{array}$ & $\underset{\sim}{\stackrel{9}{~}}$ & & $\stackrel{8}{\vec{v}}$ & \pm & $\stackrel{1}{\grave{n}}$ & s. & $b_{m}^{1}$ & $\frac{1}{4}$ & 8 & 8 & & $\frac{1}{\Delta} \stackrel{\circ}{\infty}$ & $\dot{\circ} \stackrel{\ominus}{=}$ & $\stackrel{8}{\circ}$ & $\begin{array}{l}8 \\
\frac{n}{n} \\
\end{array}$ & \\
\hline & 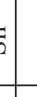 & ' & $\stackrel{ }{1}$ & in & & $\vartheta$ & $\frac{1}{m}$ & $\Rightarrow$ & 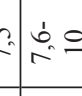 & $\stackrel{n}{I}$ & 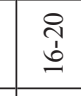 & $n$ & ¿ & & $\begin{array}{l}0 \\
\frac{\pi}{2} \\
\end{array}$ & $\frac{n}{m}$ & $\stackrel{n}{\frac{n}{n}}$ & $\stackrel{n}{\wedge}$ & \\
\hline & $?$ & $N$ & $\stackrel{n}{n}$ & iे & & $\vec{v}$ & 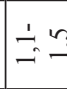 & $\stackrel{b}{b}$ & 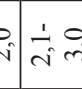 & $\dot{m}$ & $\stackrel{\vec{f}}{\rightarrow}$ in & $n$ & in & & $\frac{1}{n}=$ & $\stackrel{\sim}{\stackrel{1}{ \pm}}$ & $\begin{array}{l}\text { గे } \\
\text { iे }\end{array}$ & in & 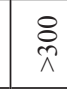 \\
\hline & 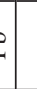 & - & $\begin{array}{l}\text { के } \\
\text { in }\end{array}$ & ন & & $\stackrel{\circ}{\mathrm{v}}$ & 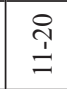 & 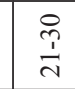 & $\frac{q}{m}$ & $\begin{array}{l}\frac{1}{n} \\
\frac{1}{7}\end{array}$ & $\begin{array}{l} \\
\\
i n \\
\text { in }\end{array}$ & लै & 8 & & $\div 8$ & 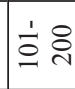 & 完 & 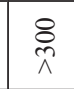 & $\begin{array}{l}0 \\
0\end{array}$ \\
\hline & 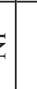 & $N$ & $\stackrel{n}{n}$ & ले & & $\stackrel{n}{v}$ & 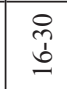 & $\frac{n}{m}$ & $\frac{R}{i}$ & $\div \&$ & $\stackrel{\circ}{\circ}$ & in & $\stackrel{\circ}{n}$ & & $\begin{array}{ll}1 & 0 \\
& \stackrel{3}{n}\end{array}$ & 离 & 咅怘 & 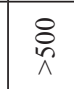 & $\begin{array}{l}8 \\
\text { in }\end{array}$ \\
\hline & 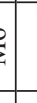 & $N$ & $\begin{array}{l}\dot{\alpha} \\
\dot{0}\end{array}$ & $\stackrel{i}{m}$ & & $\vec{v}$ & 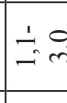 & $\frac{10}{m}$ & $\therefore \frac{1}{m}=0$ & $\stackrel{n}{=}$ & \begin{tabular}{l}
\multirow{1}{*}{} \\
b
\end{tabular} & r & ¿ & & $\begin{array}{l}0 \\
\stackrel{n}{2} \\
\end{array}$ & \begin{tabular}{|l|} 
\\
in \\
d.
\end{tabular} & $\frac{1}{n} \stackrel{8}{=}$ & $\underset{\wedge}{\stackrel{8}{\wedge}}$ & \&્ત \\
\hline & 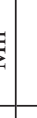 & $m$ & 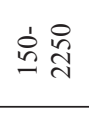 & 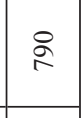 & & 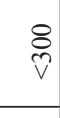 & 률요 & $\frac{1}{2}$ & $\stackrel{0}{\circ}$ & bे & 家 & : & $\begin{array}{l}8 \\
\text { तె }\end{array}$ & & 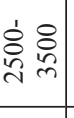 & 完各 & 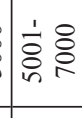 & $\underset{\wedge}{\stackrel{0}{\circ}}$ & \\
\hline & 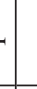 & , & $\dot{n}=$ & $n^{2}$ & & $\begin{array}{l}n \\
\tilde{v} \\
i\end{array}$ & is o & $\frac{4}{n}$ & 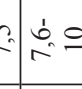 & +4 & $\frac{1}{\cos ^{2}}$ & q & q & & 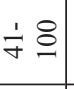 & $\stackrel{1}{\circ}$ & ì & 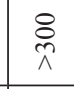 & \\
\hline & 20 & - & $\begin{array}{l}1 \\
0\end{array}$ & $\frac{9}{0}$ & & $\overrightarrow{v^{\prime}}$ & $\stackrel{1}{2}$ & 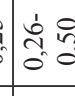 & $b_{0} \frac{1}{n} 0$ & $\Leftrightarrow$ & $=\stackrel{b}{\circ}$ & $\vec{i}$ & $\sim$ & & $\begin{array}{cc}\dot{1} & 0 \\
\vec{i} & \text { ले }\end{array}$ & $\frac{1}{m}$ in & $\therefore \circ$ & $\stackrel{\circ}{\wedge}$ & $\stackrel{\circ}{\wedge}$ \\
\hline & - & - & $\dot{t} \underset{\Xi}{\Phi}$ & $\stackrel{\mathscr{\delta}}{a}$ & & $\stackrel{\mathbb{V}}{\mathrm{V}}$ & : & 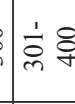 & $\frac{b}{4}$ & 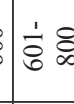 & 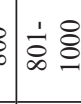 & 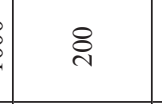 & ఏ & & $\begin{array}{l}1 \\
\vdots \\
0\end{array}$ & in & 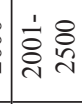 & $\begin{array}{l}\text { Oे } \\
\text { त्र }\end{array}$ & \\
\hline & 5 & $N$ & 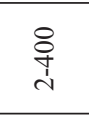 & లి & & $\stackrel{\circ}{v}$ & $\stackrel{\sim}{\stackrel{\sim}{I}}$ & $\begin{array}{l}0 \\
\text { in } \\
\vdots \\
\text { in }\end{array}$ & $\frac{n}{n}$ & $\frac{8}{6}$ & $\stackrel{1}{ \pm}$ & 8 & $\stackrel{\circ}{n}$ & & 离。 & 离 & 鬲品 & $\stackrel{8}{n}$ & 各 \\
\hline & 5 & N & 守穽 & $\bar{\sigma}$ & & $\stackrel{?}{v}$ & $\frac{P}{i}$ & $\div \&$ & $=\frac{1}{0}$ & $\frac{1}{\sqrt{n}} \stackrel{0}{\circ}$ & bे & \& & ถู & & $\begin{array}{ll}1 & 0 \\
& 0 \\
\end{array}$ & 雍 \& & in & $\stackrel{\substack{n \\
\wedge}}{n}$ & $\begin{array}{l}\stackrel{\circ}{\infty} \\
\wedge \\
\end{array}$ \\
\hline & 3 & $\alpha$ & $\frac{\infty}{7}$ & 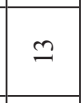 & & iv & $\dot{m}=$ & $\stackrel{\text { I }}{\Xi}$ & $\frac{0}{i}$ & $\frac{q}{m}$ & $\begin{array}{l}0 \\
\frac{n}{7} \\
\end{array}$ & ㅇ & in & & $\dot{1} \stackrel{8}{0}$ & $\stackrel{1}{\circ}$ & $\stackrel{1}{\stackrel{2}{n}}$ & 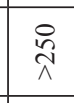 & 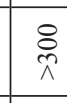 \\
\hline & 5 & - & $\begin{array}{l}1 \\
\dot{1} \infty \\
0\end{array}$ & $\overrightarrow{0}$ & & $\overrightarrow{\mathrm{v}}$ & $\begin{array}{l}1 \\
\pm 0 \\
0\end{array}$ & $\begin{array}{lll}0 & 0 \\
0 & 0 & 0 \\
0 & 0 & 0\end{array}$ & $\frac{1}{\Delta} 0$ & 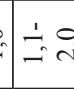 & $\dot{i} \vec{i} \dot{ }$ & $\sim$ & $m$ & & 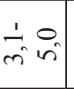 & $\dot{4}=$ & 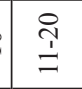 & $\stackrel{\wedge}{\wedge}$ & त्रे \\
\hline & 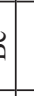 & $N$ & $\begin{array}{l}\dot{\alpha} \\
\dot{0}\end{array}$ & $\tilde{i}$ & & $\vec{v}$ & $\doteq 0$ & $\overrightarrow{\vec{i}}$ & $=\frac{1}{m}$ & $\frac{1}{n}=$ & $\therefore \stackrel{b}{\therefore}$ & 으 & $\circ$ & & 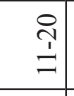 & 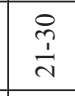 & $\frac{n}{m}$ & $i$ & \\
\hline & & $m$ & 字昌 & \& & & $\stackrel{\odot}{\nabla}$ & ᄒ্ল & 宗各 & bi & 官ঃ & م่ & \& & $\simeq$ & & 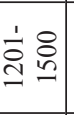 & 芒 。 & 完总 & ¿্口 & 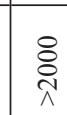 \\
\hline & & $N$ & $\dot{m}$ & $R$ & & $\stackrel{?}{\mathrm{~g}}$ & $\begin{array}{l}8 \\
\\
\\
\end{array}$ & 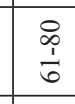 & $\frac{1}{\infty} \Phi$ & $\stackrel{0}{\circ}$ & $\frac{1}{2}$ & $=$ & 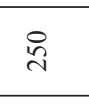 & & 离 & 光号 & 葛高 & $\underset{\wedge}{\stackrel{一}{~}}$ & \\
\hline & & - & $\stackrel{1}{I}$ & is & & $\stackrel{0}{\tilde{v}}$ & $\dot{m}$ in & $\frac{1}{n}=$ & 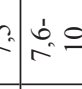 & $\stackrel{n}{I}$ & 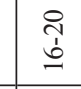 & $\stackrel{\circ}{i}$ & ¿ & పี & $\begin{array}{l}0 \\
\stackrel{i}{\sim} \\
\end{array}$ & $\frac{i}{m}$ & $\frac{n}{n}$ & $\stackrel{n}{\wedge}$ & in \\
\hline & & ' & $\stackrel{1}{0} \stackrel{\infty}{0}$ & $\because$ & & $\hat{v}$ & $\begin{array}{l}1 \\
m \\
0.0\end{array}$ & $\left\{\begin{array}{l}1 \\
\vec{n} \\
0\end{array}\right.$ & 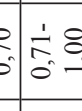 & 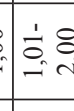 & i & - & $m$ &.$\cong$ & $\begin{array}{ll}n \\
m \\
m\end{array}$ & $\frac{0}{\frac{1}{n}}$ & $\dot{0}$ & त्र & \\
\hline & & 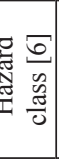 & 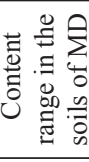 & 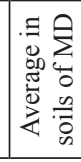 & & $\frac{3}{3}$ & 弪 & 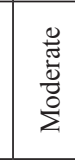 & 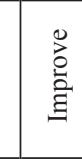 & 总 & 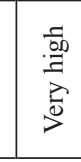 & 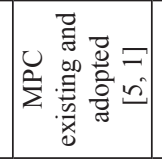 & 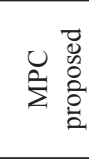 & & ב⿱ & 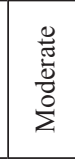 & 咅 & 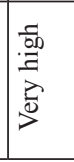 & $\begin{array}{l}\bar{n} \\
\dot{0} \\
\dot{\Sigma}\end{array}$ \\
\hline
\end{tabular}




\section{Results and discussion}

Generalizing the long-term data of numerous studies of trace elements in Moldova we propose a scale of environmental regulation of trace elements (table), for soils with neutral or slightly alkaline reaction $(\mathrm{pH} 6,0-$ $8,5)$. Indicators of the scale are quite flexible values, taking into account the average content of chemical elements in soils of Moldova, their variability depending on the concentration.

Levels of pollutants justified in dependence on the adverse effects that have trace elements, especially on plants and ground waters, and then - on the human body. There is no doubt that for a correct assessment of the soil pollution degree by trace elements its needed to have a point of reference (background, native content) and knowledge of MPC (MAC). Proposed scale of the content levels and contamination may help to consider a number of shortcomings that are available in this area in Moldova.

First, eliminate the existing gaps and inconsistencies between background and soil content, and MPC of elements (B, Ba, Cr, As, Sn), reproved 22.10.2004 (M.O. № 189-192), which are, $\mathrm{mg} / \mathrm{kg}$ :

1) Below average in the soils of Moldova (As -2,0 with an average 5,0; $\mathrm{Sn}-4,5$ with an average 5,0);

2) Equal to the average content $(\mathrm{Cr}-90$ with an average 91$)$;

3) Equal or below to the maximum content $(\mathrm{Pb}-32$ with a maximum of $30 ; \mathrm{V}-150$ with a maximum of 165 ; $\mathrm{Mn}-1500$ with maximum of 2250).

A similar situation exists for $\mathrm{Ba}, \mathrm{F}, \mathrm{Zn}$ (first variant), Ti [2] and $\mathrm{Ag}, \mathrm{Ni}, \mathrm{B}, \mathrm{Cu}$ and $\mathrm{Mo}$ [3]. Therefore, at this moment we can not correctly determinate the degree of soil contamination with 15 elements (23 analyzed), to identify preventive measures and methods of soil remediation. Secondly, to remedy the lack of data on the background content of some elements, as Ag, As, Be, Sn, Sb etc.

When comparing the pollution formal [5] and proposed levels (table), the concentration convergence is very strong on the pollution level named "very high". Values of $\mathrm{Cd}, \mathrm{Co}, \mathrm{Cr}, \mathrm{Cu}, \mathrm{Mo}, \mathrm{Ni}, \mathrm{Hg}$ are identical or very similar; for $\mathrm{As}, \mathrm{Bd}, \mathrm{Zn}$ - differ by 1,5 times; Pb and V - by 2 times. When compared with the developed MPC and MAC of different countries (WHO) shows that on the 11 items they are the same, on the 9 (B, Ba, Cr, F, Mo, Ni, Ti, Zr, V) they exceed them, because of the high content of these elements in the chernozems of in Moldova, and $3(\mathrm{~Pb}, \mathrm{Sn}, \mathrm{Zn})-\mathrm{lower}$ due its weaker anthropogenic pollution of country soils.

\section{Conclusion}

The proposed scale of content levels and soil contamination (concentrations) are justified, depending on the size of the adverse effects that have trace elements in soils, plants, soil biota, ground waters and more - per person. Proposed scale of content levels (6 grades) and pollution level (4 grades) along with equalized MPC may help to consider a number of shortcomings that occur in this area and improve the practical application and validity of the assessment of soil contamination.

\section{References}

[1]. Дмитриев М.Т., Казнина Н.И., Пинигина И.А. Санитарно-химический анализ загрязняющих веществ в окружающей среде.// Справочник. М.: Химия, 1989, 368 с.

[2]. Гончарук Е.И., Сидоренко Г.Е. Гигиеническое нормирование химических веществ в почвах. М.: Медицина, 1986, 320 c.

[3]. Меренюк Г.В. Загрязнение окружающей среды и здоровье человека. Кишинев: Штиинца, 1984,144 с.

[4]. Monitorul oficial al Republicii Moldova. Nr. 112-114 din 05.09.2000, p.11-14.

[5]. Monitorul oficial al Republicii Moldova. Nr. 189-192 din 22.10.2004, p.67-73.

[6]. ГОСТ 17.4.1.02-83. Классификация химических веществ для контроля загрязнений. Л:1983, 16 с. 